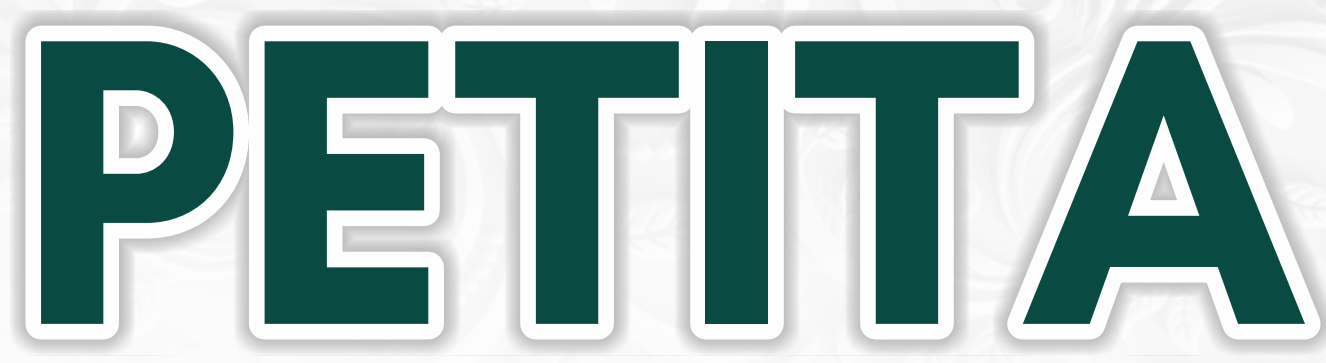

Jurnal Kajian Ilmu Hukum dan Syariah

Published By:

Lembaga Kajian Konstitusi Indonesia (LKKI)

Fakultas Syariah dan Hukum Universitas Islam Negeri (UIN) Ar-Raniry Banda Aceh Jl. Syeikh Abdul Rauf, Kopelma Darussalam Banda Aceh, Telp: 0651-7557442 Website: http://petita.ar-raniry.ac.id 


\section{Contents}

EKSISTENSI BITCOIN DALAM PERSPEKTIF MAQĀṢID AL-SYAR'ĪYAH

(Dara Lidia, Jabbar Sabil \& Syarifuddin Usman / 104-113)

TATACARA PENETAPAN BATAS TANAH DIKALANGAN MASYARAKAT KECAMATAN BAKONGAN TIMUR DITINJAU MENURUT KONSEP MAL 'UQAR

(Elida Gusmira, Saifuddin Sa'dan \& Faisal Fauzan / 114-127)

TINJAUAN HUKUM ISLAM TERHADAP SISTEM PENYELESAIAN WANPRESTASI PRODUK ARRUM DI PEGADAIAN SYARIAH ACEH BESAR

(Asdi Marni, Edi Darmawijaya \& Faisal Fauzan / 128-136)

SANKSI ADAT BAGI PELAKU KEKERASAN FISIK DITINJAU MENURUT HUKUM PIDANA ISLAM (Studi Terhadap Adat Kampung Taman Firdaus, Kecamatan Pintu Rime Gayo, Kabupaten Bener Meriah)

(Abdul Rahman, Jamhuri \& Irwansyah / 137-144)

DAMPAK PEMEKARAN DAERAH PADA PELAYANAN PUBLIK DITINJAU MENURUT SISTEM HUKUM INDONESIA

(Ali Abubakar, Sitti Mawar \& Nurdin Syah / 145-155)

MARK UP PENJUALAN HARGA TIKET BUS PADA LOKET TERMINAL BATOH DALAM PERSPEKTIF TAS'IR AL-JABAR (Studi tentang Penyimpangan Harga Dari Ketetapan Organda Banda Aceh)

(Aris Rahmaddillah / 156-169)

PROSES PENIMBANGAN IKAN DI TEMPAT PELELANGAN IKAN LAMPULO KOTA BANDA ACEH DALAM PERSPEKTIF MA'QUD 'ALAIH

(Alfata / 170-175)

SANKSI BAGI PELAKU ZINA (Perbandingan Qanun No. 6 Tahun 2014 Dan Enakmen Jenayah Syariah Negeri Selangor No. 9 Tahun 1995 Seksyen 25)

(Ali Abubakar, Badrul Munir \& Cempaka Sari Harahap / 176-200) 


\title{
DAMPAK PEMEKARAN DAERAH PADA PELAYANAN PUBLIK DITINJAU MENURUT SISTEM HUKUM INDONESIA
}

\author{
Ali Abubakar, Sitti Mawar \& Nurdin Syah \\ Prodi Ilmu Hukum \\ Fakultas Syariah dan Hukum UIN Ar-raniry \\ Email: aliabubakar@ar-raniry.ac.id
}

\begin{abstract}
Region expansion is one of the main keys in providing services to the community, after the establishment of Law Number 22 of the Year 1999 concerning the regional government. This law was established due to problems arose mainly concerning the lack of public services, the extent of territory, territorial borders, ethnic and cultural differences, and unfair development in all regions and others, leading to many problems in the community. The results of this study revealed that region expansion had positive implications in term of social, political and cultural recognition of regional communities. Through the expansion policy, community entities with a long history of cohesiveness and greatness have been recognized as new autonomous regions. This recognition has, in turn, positively contribute to community satisfaction, which ultimately increases the regional support for central governments. It can be concluded that regional expansion policies shorten the geographical distance between citizen settlements and service centers, and narrow the range of control between the local governments and its lower government units. In addition, the expansion enables the government to bring new types of service to the area, such as electricity, water, and health services.
\end{abstract}

Keywords: Impact of Expansion, Public Services, Special Autonomy

\begin{abstract}
Abstrak: Pemekaran daerah merupakan salah satu kunci utama dalam memberikan pelayanan kepada masyarakat, setelah disahkannya atas UU No. 22 Tahun 1999 tentang pemerintahan daerah, lahirnya undang-undang ini dikarenakan adanya permasalahanpermasalahan yang timbul terutama dari segi kurangnya pelayanan publik, luasnya wilayah, batas wilayah, perbedaan suku dan budaya,dan pembangunan yang tidak merata di seluruh daerah dan lain-lain, sehingga menimbulkan banyak permasalahan dalam masyarakat. Adapun yang menjadi permasalahan dalam skripsi ini adalah bagaimana sistem hukum Indonesia mengatur tentang pemekaran daerah, sebagai pelayanan publik, bagaimana dampak pemekaran daerah pada pelayanan publik.oleh karena itu tujuan dari penelitian ini adalah untuk memperoleh data empiris yang valid, dan objektif serta mengetahui bagaimana sistem hukum Indonesia mengatur tentang pemekaran daerah sekaligus dampak dari pemekaran daerah tersebut terhadap pelayanan publik. Dalam penelitian ini metode yang digunakan adalah metode penelitian yuridis normatif yaitu mengkaji permasalahan berdasarkan aturan-aturan hukum,dan penerapan hukum yang berlaku. Dari hasil penelitian ini pemekaran daerah membawa implikasi positif dalam bentuk pengakuan sosial, politik dan kultural masyarakat daerah.melalui kebijakan pemekaran, entitas masyarakat yang mempunyai sejarah kohesivitas dan kebesaran yang panjang, memperoleh pengakuan sebagai daerah otonom baru. Pengakuan ini pada
\end{abstract}


gilirannya memberikan kontribusi positif terhadap kepuasan masyarakat, sehingga meningkatkan dukungan daerah terhadap pemerintah nasional.Intisari kesimpulan yang dapat diambil adalah Kebijakan pemekaran daerah mampu memperpendek jarak geografis antara pemukiman penduduk dengan sentra pelayanan, juga mempersempit rentang kendali antara pemerintah daerah dengan unit pemerintahan di bawahnya. Disamping itu, pemekaran juga memungkinkan untuk menghadirkan jenis-jenis pelayan baru di Daerah tersebut seperti pelayanan listrik, Air, Kesehatan dan sebagainya.

Kata Kunci: Dampak Pemekaran, Pelayanan Publik.

\section{Pendahuluan}

Isu pemekaran daerah semakin menguat sejak disahkannya UU No. 22 Tahun 1999 tentang Pemerintah Daerah, UU tentang menyatakan bahwa dalam rangka pelaksanaan asas desentralisasi dibentuk dan disusun daerah provinsi, daerah kabupaten dan daerah kota yang berwenang mengatur dan mengurus kepentingan masyarakat setempat menurut prakarsa sendiri berdasarkan aspirasi masyarakat. Dalam konteks desentralisasi tersebut, pemerintah mengabaikan otonomi daerah yang seluas-luasnya, kecuali urusan pemerintah yang menjadi urusan pemerintah pusat, dengan tujuan meningkatkan kesejahteraan masyarakat, pelayanan umum dan daya saing daerah. ${ }^{1}$

pemekaran daerah adalah pemecahan daerah provinsi, daerah kabupaten dan daerah kota menjadi lebih dari satu daerah. Pemekaran daerah di Indonesia adalah pembentukan daerah administratif baru di tingkat provinsi maupun kota dan kabupaten dari induknya. Landasan hukum terbaru untuk pemekaran daerah di Indonesia adalah UU No. 23 Tahun 2014 tentang Pemerintahan Daerah.Undang-Undang Dasar 1945 tidak mengatur perihal pembentukan daerah atau pemekaran suatu wilayah secara khusus, namun disebutkan dalam Pasal 18B ayat (1) "Negara mengakui dan menghormati satuan-satuan pemerintahan daerah yang bersifat khusus atau bersifat istimewa yang diatur dengan undang-undang". Selanjutnya, pada ayat (2) Pasal yang sama tercantum kalimat sebagai berikut. "Negara mengakui dan menghormati kesatuan-kesatuan masyarakat hukum adat serta hak-hak tradisionalnya sepanjang masih hidup dan sesuia dengan perkembangan masyarakat dan prinsip Negara Kesatuan Republik Indonesia, yang diatur dalam undang-undang."

Terdapat beberapa alasan kenapa pemekaran daerah sekarang menjadi salah satu pendekatan yang cukup diamati dalam kaitannya dengan penyelenggaraan pemerintahan daerah dan peningkatan pelayanan publik, yaitu salah satunya adalah alasan mendekatkan pelayanan kepada masyarakat yang mana hal ini dijadikan alasan utama karena adanya kendala geografis, infrastruktur dan sarana perhubungan yang minim. ${ }^{2}$

Pemekaran daerah kabupaten/kota menjadi beberapa daerah kabupaten baru, pada dasarnya merupakan upaya untuk meningkatkan kualitas pelayanan dan kesejahteraan masyarakat.Pada prinsipnya pemekaran daerah bertujuan untuk meningkatkan kesejahteraan masyarakat, dengan meningkatkan dan mempercepatpelayanan, demokrasi, perekonomian daerah, pengelolaan potensi daerah, keamanan ketertiban, hubungan yang serasi antara pusat dan daerah. ${ }^{3}$ Pada hakekat tujuan pemekaran daerah sebagai upaya peningkatan sumber daya berkelanjutan, meningkatkan keserasian dan perkembangan antar sektor, memperkuat integrasi nasional.untuk mencapai tujuan itu semua perlu adanya peningkatan kualitas sumber daya aparatur disegala bidang, karena peran sumber

$1 \quad$ Ubaedillah dan Abdul Rozak, Pendidikan Kewarga[Negar]an (Civic Education) Pancasila, Demokrasi, HAM, Dan Masyarakat Madani (Icce UIN Syarif Hidayatullah 2014), hlm. 175. 2 'Https://Id.Answers.Yahoo.Com/Question/Index?Qid=20140303043133aatxilp.' < < 2017.

3 Ubaedillah dan Abdul Rozak (n 1), hlm. 189. 
daya manusia diharapkan dapat meningkatkan kinerja organisasi dalam memberikan pelayanan prima kepada masyarakat, serta mendukung dalam pengembangan wilayah daerah.

Dampak dari pemekaran daerah merupakan hambatan yang cukup serius dan sering dihadapi oleh pemerintah kabupaten/kota baru hasil dari pemekaran daerah yaitu pelaksanaan pemerintahan dan pembangunan serta pemberian pelayanan kepada masyarakat belum sesuai kualitas kerja aparatur dengan apa yang diinginkan masyarakat, kurang tersedianya tenaga manusia dalam hal ini sumber daya manusia yang ahli dan sesuai dengan bidang kerjanya, kurang terampilnya aparatur pemerintah daerah dalam menangani tugas-tugas yang dibebankan kepadanya, dan kondisi kapasitas administratif pegawai yang tidak memadai.

Secara umum bahwa tujuan pembentukan atau pemekaran daerah adalah peningkatan kualitas hidup masyarakat, baik secara sosio-koltural, politik maupun ekonomi. Oleh karena itu, walaupun pembentukan daerah otonomi baru akan meningkatkan biaya penyelenggaraan pemerintahan, namun peraturan pemerintah No. 129 Tahun 2000 Pasal 2 memiliki tujuan pembentukan, pemekaran, penghapusan dan penggabungan daerah adalah untuk meningkatkan kesejahteraan masyarakat.

Dalam sistem hukum di Indonesia peraturan pemerintah mengatur antara lain tentang persyaratan, kriteria, prosedur pembentukan/pemekaran daerah, pembiayaan dalam rangka pemekaran, penghapusan dan penggabungan daerah.Aturan tersebut merupakan rambu-rambu yang di jadikan kriteria atau daerah acuan dalam menyikapi keinginan masyarakat.

Jenis penelitian yang dipergunakan disini adalah yuridis normatif.Penelitian yang dikaji secara yuridis normatif adalah mengkaji permasalahan yang timbul dengan berlandaskan aturan-aturan hukum, teori-teori dan penerapan aturan hukum yang berlaku. ${ }^{4}$

Pendekatan masalah yang digunakan adalah Pendekatan konseptual dilakukan dengan menelaah aturan-aturan hukum yang ada maupun peraturan perundang-undangan terkait dengan sistem hukum Indonesia.

Kemudian Pendekatan perundang-undangan (the statute approach) dilakukan dengan menelaah semua undang-undang dan regulasi yang menyangkut paut dengan dampak pemekaran yang sedang terjadi.

Karena penelitian ini bersifat yuridis normatif, maka bahan hukum yang digunakan yang terdiri atas:

1) Bahan hukum primer adalah bahan hukum yang memiliki kekuatan mengikat. ${ }^{5}$ Jika ditinjau dari hukum nasional, maka bahan hukum primer yang digunakan dalam penelitian ini adalah:

a. Undang-Undang 1945 Pasal 18B ayat (1).

b. Undang-Undang No.22 Tahun 1999tentang Pemerintahan Daerah

c. Peraturan Pemerintah Republik Indonesia No. 78 Tahun 2007 tentang Tata Cara Pembentukan, Penghapusan, dan Penggabungan Daerah.

d. Peraturan Pemerintah No. 129 Tahun 2000 tentang Tata Cara Pembentukan, Penghapusan, dan Penggabungan Daerah.

e. Undang-Undang Republik Indonesia No. 32 Tahun 2004 tentang Pemerintahan Daerah.

4 Soerjono Soekamto dan Sri Mamudji, Penelitian Hukum Normatif Suatu Tinjauan Singkat (Raja Grafindo Persada 2003), hlm. 14.

5 Ronny Hanitijo Soemitro, Metode Penelitian Hukum Dan Jurimetri (Ghalia Indonesia 1994), hlm. 10. 
f. Undang-Undang Republik Indonesia No. 23 Tahun 2014 tentang Pemerintahan Daerah.

2) Sedangkan bahan hukum sekunder adalah bahan-bahan yang erat hubungannya dengan bahan hukum primer. ${ }^{6}$ Contohnya: buku, artikel, laporan penelitian dan berbagai karya tulis ilmiah lainnya. Bahan hukum sekunder yang digunakan dalam penulisan ini berupa buku-buku literatur, karya ilmiah/pendapat para sarjana dan artikel yang berkaitan erat dengan pokok bahasan yang di bahas dalam permasalahan.

3) Bahan hukum tersier, yaitu sumber bahan hukum primer maupun sekunder. Bahan hukum tersier dalam penulisan ini terdiri atas kamus hukum, Kamus Besar Bahasa Indonesia, dan buku-buku pelajaran yang bersifat non hukum.

\section{Pembahasan}

\section{Persyaratan Pemekaran Daerah}

Setiap daerah melakukan pemekaran dan tidak ada satu pun daerah yang ingin melakukan penggabungan.pemekaran suatu daerah dapat menjadi dua daerah atau bisa lebih. Untuk hal ini, ditentukan persyaratan bahwa pemekaran itu dapat dilakukan apabila mencapai batas minimal usia penyelenggaraan pemerintahan dalam ketentuan ini ialah untuk provinsi 10 tahun, kabupaten/kota 7 tahun, dan kecamatan 5 tahun. Pembentukan suatu daerah harus memenuhi persyaratan administratif, teknis dan fisik kewilayahan.

Dalam Peraturan Pemerintah Republik Indonesia No. 78 Tahun 2007 tentang Tata Cara Pembentukkan, Penghapusan, dan Penggabungan Daerah juga disebutkan beberapa syarat dari pemekaran suatu wilayah ataupun daerah yang tercantum dalam Pasal 5 ayat (1) syarat administratif pembentukan daerah provinsi sebagaimana dimaksud dalam Pasal 4 ayat (1) meliputi:

a. keputusan masing-masing DPRD kabupaten/kota yang akan menjadi cakupan wilayah calon provinsi tentang persetujuan pembentukan calon provinsi berdasarkan hasil Rapat Paripurna.

b. keputusan bupati/walikota ditetapkan dengan keputusan bersama bupati/ walikota wilayah calon provinsi tentang persetujuan pembentukan calon provinsi.

c. keputusan gubernur tentang persetujuan pembentukan calon provinsi; dan

d. rekomendasi Menteri.

Selanjutnya Pasal 5 ayat (2), syarat administratif pembentukan daerah kabupaten/kota dimaksud dalam Pasal 4 ayat (2) meliputi:
a. keputusan DPRD kabupaten/kota induk tentang persetujuan pembentukan calom kabupaten/kota.
b. keputusan bupati/walikota induk tentang persetujauan pembentukan calon kabupaten/kota.
c. keputusan DPRD provinsi tentang persetujuan pembentukan calon kabupaten/ kota; dan
d. rekomendasi Menteri. ${ }^{7}$

\section{Prosedur Pemekaran Daerah}

Tahapan dan prosedur pembentukan daerah kabupaten/kota menurut PP No. 78/2007 tentang Persyaratan Pembentukan dan Kriteria Pemekaran, Penghapusan, dan

6 Ibid., hlm. 12.

7 Peraturan Pemerintah Republik Indonesia Nomor 78 Tahun 2007 tentang Tata Cara Pembentukan, Penghapusan, dan Penggabungan Daerah, hlm. 9-11. 
Penggabungan Daerah sebagai pengganti PP No. 129/2000, pada.

Pasal 15.

Pembentukan daerah provinsi sebagaimana dimaksud dalam Pasal 2 ayat (3) huruf b dilaksanakan dengan tahapan sebagai berikut:

a. Aspirasi sebagian besar masyarakat setempat dalam bentuk keputusan BPD untuk Desa dan forum komunikasi kelurahan atau nama lain untuk kelurahan di wilayah provinsi atau kabupaten/kota yang akan dimekarkan.

b. Keputusan DPRD kabupaten/kota berdasarkan aspirasi sebagian besar masyarakat setempat.

c. Bupati/walikota dapat memutuskan untuk menyetujui atau menolak aspirasi sebagaimana dimaksud dalam huruf a dalam bentuk keputusan bupati/ walikota.

d. keputusan masing-masing bupati/walikota sebagaimana dimaksud dalam huruf c disampaikan kepada masing-masing gubernur yang bersangkutan dengan melampirkan.

1. Dokumen aspirasi masyarakat dan.

2. Keputusan DPRD kabupaten/kota dan keputusan bupati/walikota sebagaimana dimaksud dalam Pasal 5 ayat (1) huruf a dan huruf $b$.

e. Dalam hal gubernur menyetujui usulan pembentukan provinsi sebagaimana yang diusulkan oleh bupati/walikota dan berdasarkan hasil kajian daerah, usulan pembentukan provinsi tersebut selanjutnya disampaikan kepada DPRD provinsi yang bersangkutan.

f. Setelah adanya keputusan persetujuan dari DPRD provinsi, masing-masing gubernur menyampaikan usulan pembentukan provinsi kepada Presiden melalui Menteri dengan melampirkan.

1. Hasil kajian daerah.

2. Peta wilayah calon provinsi.

3. Keputusan DPRD kabupaten/kota dan keputusan bupati/walikota sebagaimana dimaksud dalam Pasal 5 ayat (1) huruf a dan huruf b. dan

4. Keputusan DPRD provinsi sebagaimana dimaksud dalam Pasal 5 ayat (1) huruf d.

Pasal 16

Tata cara pembentukan daerah kabupaten/kota sebagaimana dimaksud dalam Pasal 2 ayat (4) huruf a dilaksanakan sebagai berikut.

a. Aspirasi sebagian besar masyarakat setempat dalam bentuk Keputusan BPD untuk Desa dan Forum Komunikasi Kelurahan atau nama lain untuk Kelurahan di wilayah yang menjadi calon cakupan wilayah Kabupaten/Kota yang akan dimekarkan.

b. DPRD Kabupaten/Kota dapat memutuskan untuk menyetujui atau menolak aspirasi sebagaimana dimaksud dalam huruf a dalam bentuk Keputusan DPRD bersadarkan aspirasi sebagian besar masyarakat setempat yang diwakili oleh BPD untuk desa atau nama lain dan Forum Komunikasi Kelurahan untuk kelurahan atau nama lain.

c. Bupati/Walikota memutuskan untuk menyetujui atau menolak aspirasi sebagaimana dimaksud dalam huruf a dalam bentuk keputusan Bupati/ Walikota berdasarkan hasil kajian daerah.

d. Bupati/Walikota mengusulkan pembentukan Kabupaten/Kota kepada 
Gubernur untuk mendapatkan persetujuan dengan melampirkan:

1. Dokumen aspirasi masyarakat di calon Kabupaten/Kota.

2. Hasil kajian daerah.

3. Peta wilayah calon Kabupaten/Kota. dan

4. Keputusan DPRD Kabupaten/Kota dan keputusan Bupati/Walikota sebagaimana dimaksud dalam pasal 5 ayat (2) huruf a dan huruf b

e. Gubernur memutuskan untuk menyetujui atau menolak usulan pembentukan Kabupaten/Kota berdasarkan evaluasi terhadap kajian daerah sebagaimana dimaksud dalam huruf c.

f. Gubernur menyampaikan usulan pembentukan calon Kabupaten/Kota kepada DPRD Propinsi.

g. DPRD Propinsi memutuskan untuk menyetujui atau menolak usulan pembentukan Kabupaten/Kota. dan

h. Dalam hal Gubernur menyetujui usulan pembentukan Kabupaten/Kota, Gubernur mengusulkan pembentukan Kabupaten/Kota kepada Presiden melalui Menteri dengan melampirkan:

1. Dokumen aspirasi masyarakat di calon Kabupaten/Kota.

2. Hasil kajian daerah.

3. Peta wilayah calon Kabupaten/Kota

4. keputusan DPRD kabupaten/kota dan keputusan bupati/walikota sebagaimana dimaksud dalam Pasal 5 ayat (2) huruf a dan huruf b dan.

5. Keputusan DPRD Propinsi sebagaimana dimaksud dalam Pasal 5 ayat (1) huruf c dan keputusan Gubernur sebagaimana dimaksud dalam Pasal 5 ayat (1) huruf d.

\section{Dampak Pemekaran Daerah}

1. Dampak pemekaran kultural.

Pemekaran daerah membawa implikasi positif dalam bentuk pengakuan sosial, politik dan kultural masyarakat daerah. Melalui kebijakan pemekaran, entitas masyarakat yang mempunyai sejarah kohesivitas dan kebesaran yang panjang, memperoleh pengakuan sebagai daerah otonomi baru. Pengakuan ini pada gilirannya memberikan kotribusi positif terhadap kepuasan masyarakat, sehingga meningkatkan dukungan daerah terhadap pemerintah nasional. ${ }^{8}$

Namun demikian, kebijakan pemekaran juga bisa memicu koflik yang pada gilirannya juga menimbulkan masalah horizontal dan vertikal dalam masayarakat. Sengketa antara pemerintah daerah induk dengan pemerintah daerah pemekaran dalam hal pengalihan aset dan batas wilayah, seringkali berimplikasi pada ketegangan antar kubu masyarakat dan antara masyarakat dengan pemerintah.

2. Pelayanan publik

Kebijakan pemekaran daerah mampu memperpendek jarak geografis antara pemukiman penduduk dengan sentra pelayanan, juga mempersempit rentang kendali antara $8 \quad$ Lihat bagaimana entitas masyarakat begitu penting untuk diakui sebagai upaya menghindari konflik dalam Fikarwin Zuska, 'Politik Etnisitas Dalam Pemekaran Daerah' (2013) 33 Antropologi Indonesia <http://journal.ui.ac.id/index.php/jai/article/view/2464>; Nurul Aini, 'Domestifikasi Etnisitas: Pemekaran Wilayah Dan Rutinisasi Kekerasan Antar Etnis Di Maluku Utara' (2015) 1 Jurnal Pemikiran Sosiologi 103 <https://jurnal.ugm.ac.id/jps/article/view/23434>. Lihat juga Tommy Firman, 'Territorial Splits (Pemekaran Daerah) in Decentralising Indonesia, 2000-2012: Local Development Drivers or Hindrance?' [2013] Space and Polity. 
pemerintah daerah dengan unit pemerintahan di bawahnya. Disamping itu, pemekaran juga memungkinkan untuk menghadirkan jenis-jenis pelayan baru, seperti pelayan listrik, telepon, serta fasilitas urban lainnya, terutama di wilayah ibukota daerah pemekaran.

Tetapi, pemekaran juga menimbulkan implikasi negatif bagi pelayan publik, terutama pada skala nasional, terkait dengan alokasi anggaran untuk pelayanan publik yang berkurang. Hal ini disebabkan adanya kebutuhan belanja aparat dan infrastruktur pemerintahan lainnya yang bertambah dalam jumlah yang signifikan sejalan dengan pembentukan DPRD dan birokrasi di daerah hasil pemekaran. ${ }^{9}$

\section{Pembangunan ekonomi}

Paska terbentuknya daerah otonomi baru, terdapat peluang yang besar bagi ekselerasi pembangunan ekonomi di wilayah yang baru. Bukan hanya infrastruktur pemerintahan yang terbangun, tetapi juga infrastruktur fisik dan infrastruktur kebijakan pembangunan ekonomi yang dikeluarkan oleh pemerintah daerah otonomi baru. Semua infrastruktur ini membuka peluang yang lebih besar bagi wilayah hasil pemekaran untuk mengakselerasi pembangunan ekonomi. Semakin mempermudah dalam menghadirkan investor yang berminat dalam membuka industri daerah yang menguntungkan. ${ }^{10}$

Namun, kemungkinan akselerasi pembangunan ini harus dengan besarnya anggaran yang dikeluarkan utuk membiayai belanja pegawai dan belanja operasional pemerintahan daerah. Dari sisi teoritik, belanja ini bisa diminimalisir melalui kebijakan pembangunan ekonomi yang menjangkau seluruh wilayah, sehingga akselerasi pembangunan ekonomi tetap dimungkinkan dengan harga yang murah.

\section{Dampak bagi Pertahanan, Keamanan, dan Integrasi Nasionanal}

Pembentukan daerah otonomi baru, bagi beberapa masyarakat pedalaman dan masyarakat di wilayah perbatasan merupakan isu politik nasional yang penting. Bagi masyarakat tersebut, bisa jadi mereka tidak pernah melihat dan merasakan kehadiran 'indonesia', baik dalam bentuk simbol pemerintahan, politisi, birokrasi dan bahkan kantor pemerintahan. Pemekaran daerah otonom, oleh karenanya, bisa memperbaiki kenangan politik nasional di daerah melalui peningkatan dukungan terhadap pemerintah nasional dan menghadirkan pemerintah pada level yang lebih bawah.

Akan tetapi, ongkos politik untuk menghadirkan pemerintahan daerah otonom baru ini seringkali juga bisa sangat mahal, apabila pengelolaan politik selama proses dan paska pemekaran tidak bisa dilakukan dengan baik. Sebagaimana terbukti pada beberapa daerah hasil pemekaran, ketidak mampuan untuk membangun inklusivitas politik antar kelompok dalam masyarakat mengakibatkan munculnya tuntutan untuk memekarkan lagi daerah yang baru saja mekar.

Identifikasi dampak pemekaran tersebut membawa kita pada kesimpulan bahwa banyak dampak negatif yang perlu diminimalisasi. Esensi kebijakan yang perlu dilakukan adalah merasionalitas proses kebijakan pemekaran, baik proses pengusulan pemekaran yang dilakukan oleh daerah itu sendiri, maupun proses penetapan pemekaran yang dilakukan di tingkat pusat melalui institusi yang berwenang. ${ }^{11}$

$9 \quad$ Khairul Ikhwan Damanik dkk, Otonomi Daerah, Etnonasionalisme, Dan Masa Depan Indonesia (Yayasan Pustaka Obor Indonesia 2010), hlm. 108. Lihat juga Rita Helbra Tenrini, 'Pemekaran Daerah : Kebutuhan Atau Euforia Demokrasi ? Mengapa Harus Mekar’ [2014] Pusat Kebijakan APBN BKF Republik Indonesia.

10 Deden Haria Germana, 'Tinjauan Arah Kebijakan Pembangunan Di Daerah Pada Era Otonomi Daerah' (2017) 10 KA PEMUDA 69.

11 Khairul Ikhwan Damanik dkk (n 9)., hlm. 109-110. 


\section{Manfaat Pemekaran Daerah}

Berbicara mengenai manfaat dari pemekaran wilayah adalah memberikan masukan bagi Pemerintah daerah terkait dengan kondisi riil di lapangan sehingga mempermudah atau memperpendek jangkauan pelayanan yang baik kepada masyarakat pada kondisi geogerafis yang sulit dijangkau oleh pemerintah daerah baik melalui transportasi udara, darat dan laut, dan terwujudnya keinginan masyarakat dalam mempercepat peningkatan tingkat kesejahteraan masyarakat dalam segala aspek kehidupan baik pendidikan, kesehatan, sosial budaya, dan politik serta pembangunan infrastruktur yang memadai. ${ }^{12}$

Faktor-Faktor yang Mendukung Kualitas Pelayanan Publik

\section{Faktor Kesadaran}

Kesadaran menunjukkan suatu keadaan pada jiwa seseorang, yaitu merupakan titik temu atau equilibrium dari berbagai pertimbangan sehingga diperoleh suatu keyakinan, ketenangan, ketetapan hati dan keseimbangan dalam jiwa yang bersangkutan.Barangkali kata kesadaran ini dapat dirumuskan sebagai berikut.

"Suatu proses berpikir melalui metode renungan, pertimbangan dan perbandingan, sehingga menghasilkan keyakinan, ketenangan, ketetapan hati dan keseimbangan dalam jiwanya sebagai pangkal tolak untuk perbuatan dan tindakan yang akan dilakukan kemudian."

Dengan pengertian di atas maka kesadaran adalah hasil dari suatu proses yang kadangkadang memerlukan waktu cukup lama dan dalam keadaan tenang tidak dalam keadaan emosi. Orang yang dalam keadaan emosional tidak mungkin memperoleh kesadaran. Dengan kesadaran dapat diperoleh atau ditemukan kebenaran hakiki sehingga dapat "melihat" dengan mata-hati suatu kebatilan

\section{Faktor Aturan}

Aturan adalah perangkat penting dalam segala tindakan dan perbuatan orang.Makin maju dan majemuk suatu masyarakat makin besar peranan aturan dan dapat dikatakan orang tidak dapat hidup layak dan tenang tanpa aturan.Oleh karena peranan aturan demikian besar dalam hidup bermasyarakat maka dengan sendirinya aturan harus dibuat, dipatuhi dan diawasi sehingga dapat mencapai sasaran sesuai dengan maksudnya.Dalam organisasi kerja aturan dibuat oleh manajemen sebagai pihak yang berwenang mengatur segala sesuatu yang ada di organisasi kerja tersebut.

Oleh karena setiap aturan pada akhirnya menyangkut langsung ataupun tidak langsung kepada orang, maka masalah manusia serta sifat kemanusiannya harus menjadi pertimbangan utama. Pertimbangan harus diarahkan kepada manusia sebagai subyek aturan, artinya mereka yang membuat, menjalankan, dan mengawasi pelaksanaan aturan itu, maupun manusia sebagai obyek aturan, yaitu meraka yang akan dikenai oleh aturan itu. Pertimangan pertama manusia sebagai subyek aturan ditujukan kepada hal-hal yang penting, yaitu:

a. kewenangan

Pertama-tama dalam hal pembuatan aturan, si pembuat aturan haruslah memiliki kewenangan untuk itu. Kewenangan erat hubungannya dengan sahnya suatu perbuatan atau tindakan yang diambil, termasuk pembuatan aturan yang akan mengikat berbagai pihak. Aturan yang dibuat oleh orang tidak berwenang adalah tidak sah dan tidak mempunyai kekuatan hukum.

12 'Dampak Pemekaran Wilayah Terhadap' (2012) < http://weyagunggaalexconawiarigia.blogspot. com/2012/10/Dampak-Pemekaran-Wilayah-Terhadap.Html.> accessed 25 July 2018. 
b. Pengetahuan dan pengalaman

Dengan pengetahuan dan pengalaman itu ia dapat memiliki pandangan jauh ke depan sehingga aturan yang dibuat dapat menjangkau waktu yang cukup panjang karena dapat mengantipasi segala sesuatu yang berada 5-10 tahun yang akan datang.

c. Kemampuan bahasa

Bahasa tulisan merupakan cerminan dari kehendak atau pikiran, yang berbeda dengan bahasa lisan. Dalam beberapa hal bahasa tulis yang mampu menerjemahkan secara lengkap untuk hal yang sama.

d. Pemahaman oleh pelaksana

Petugas pelaksana yang kelak akan terlibat langsung dengan aturan itu, berhadapan dengan orang, haruslah memahami terlebih dahulu maksud dan arti aturan itu. Sebab petugas itulah yang akan berhadapan langsung dengan orang yang berkepentingan, sehingga ia harus mampu memberikan penjelasan serta pelayanan yang tepat dan cepat.

e. Disiplin dalam pelaksanaan

Disiplin adalah suatu bentuk ketaatan terhadap aturan, baik tertulis maupun tidak tertulis, yang telah ditetapkan.Maksud ditumbuhkanya disiplin kecuali kepatuhan terhadap aturan juga tumbuhnya ketertiban dan efisiensi.Ketaatan terhadap aturan tertulis sudah cukup jelas, karena semua aturan tertulis pada dasarnya adalah terbuka agar diketahui oleh semua orang yang berkepentingan.

\section{Faktor Organisasi}

Organisasi pelayanan pada dasarnya tidak berbeda dengan organisasi pada umumnya, namun ada perbedaan sedikit dalam penerapannya, karena sasaran pelayanan ditujukan secara khusus kepada manusia yang mempunyai watak dan kehendak multi kompleks. Oleh karena itu organisasi yang dimaksud di sini tidak semata-mata dalam perwujudan susunan organisasi, melainkan lebih banyak pada pengaturan dan mekanisme kerjanya yang harus mampu menghasilkan pelayanan yang memadai.Karena organisasi adalah mekanisme maka perlu adanya sarana pendukung yang berfungsi memperlancar mekanisme itu.Sarana pendukung itu ialah sistem, prosedur dan metode.

\section{a. Sistem}

Sistem adalah suatu susunan atau rakitan komponen atau bagian-bagian yang membentuk satu kesatuan yang utuh dengan sifat-sifat saling tergantung, saling mempengaruhi dan saling berhubungan.

b. Prosedure

Sistem dan prosedur merupakan dwitunggal yang tak terpisahkan karena satu sama lain saling melengkapi. Sistem merupakan kerangka mekanismenya organisasi sedang prosedur adalah rincian dinamikanya mekanisme sistem.Jadi tanpa sistem prosedur tidak ada landasan berpijak untuk "berkiprah" dan tanpa prosedur suatu mekanisme sistem tidak berjalan.

c. Metode

Yang dimaksud dengan metode ialah cara yang dilakukan oleh seseorang untuk menyelesaikan suatu tahap dari rangkaian pekerjaan, yang paling mudah dan efisien diantara beberapa cara yang ada.

\section{Faktor Pendapatan}

Pendapatan ialah seluruh penerimaan seseorang sebagai imbalan atas tenaga dan/atau 
pikiran yang telah dicurahkan untuk orang lain atau badan/organisasi, baik dalam bentuk uang, aturan maupun fasilitas, dalam jangka waktu tertentu. Pada dasarnya pendapatan harus dapat memenuhi kebutuhan hidup baik untuk dirinya maupun keluarga.

\section{Faktor Kemampuan-Keterampilan}

Kemampuan berasal dari kata dasar mampu yang dalam hubungan dengan tugas/ pekerjaan berarti dapat (kata sifat/keadaan) melakukan tugas/pekerjaan sehingga menghasilkan barang atau jasa sesuai dengan yang diharapkan.Kata jadian kemampuan dengan sendirinya juga kata sifat/keadaan yang ditujukan pada sifat atau keadaan seseorang yang dapat melaksanakan tugas/pekerjaan atas dasar ketentuan-ketentuan yang ada.

Di bidang manajemen menurut Robert R. Katz ada 3 jenis kemampuan dasar yang perlu dimiliki oleh setiap manajer agar dapat melaksanakan tugasnya memimpin secara berdayaguna dan berhasil. 3 kemampuan dasar tersebut ialah, kemampuan teknik (technical skill), kemampuan bersifat manusiawi (human skill), dan kemampuan membuat konsepsi ( conceptual skill).

\section{Faktor Sarana Pelayanan}

Sarana pelayan yang dimaksud di sini ialah segala jenis peralatan, perlengkapan kerja dan fasilitas lain yang berfungsi sebagai alat utama/pembantu dalam pelaksanaan pekerjaan, dan juga berfungsi sosial dalam rangka kepentingan orang-orang yang sedang berhubungan dengan organisasi kerja itu. Fungsi sarana pelayan tersebut antara lain:

a. mempercepat proses pelaksanaan pekerjaan, sehingga dapat menghemat waktu.

b. meningkatkan produktivitas, baik barang atau jasa.

c. kualitas produk yang lebih baik/terjamin.

d. ketetapan susunan dan stabilitas ukuran terjamin.

e. lebih mudah/sederhana dalam gerak para pelakunya.

f. menimbulkan rasa kenyamanan bagi orang-orang yang berkepentingan.

g. menimbulkan perasaan puas pada orang-orang yang berkepentingan sehingga dapat mengurani sifat emosional mereka. ${ }^{13}$

\section{Kesimpulan}

1. Sistem hukum Indonesia mengatur pemekaran daerah merujuk kepada UUD 1945 dalam Pasal 18B ayat (1) dan ayat (2) Ketentuan terbaru mengenai Pemekaran Daerah dijabarkan lebih lanjut dalam undang-undang Nomor 22 Tahun 1999 yang telah di ubah dengan Undang-undang Nomor 32 Tahun 2004 tentang Pemerintahan Daerah, yang mengatur mengenai ketentuan pembentukan daerah yang disebutkan dalam Bab II Pasal 4 ayat (1). Selanjutnya landasan hukum terbaru untuk pemekaran daerah di Indonesia adalah UU No. 23 Tahun 2014 tentang Pemerintahan Daerah. yang tercantum dalam Pasal 2 ayat (1) dan (2).

2. Kebijakan pemekaran daerah mampu memperpendek jarak geografis antara pemukiman penduduk dengan sentra pelayanan, juga mempersempit rentang kendali antara pemerintah daerah dengan unit pemerintahan di bawahnya.Disamping itu, pemekaran juga memungkinkan untuk menghadirkan jenis-jenis pelayan baru, seperti pelayan listrik, telepon, serta fasilitas urban lainnya,terutama di wilayah ibukota daerah pemekaran. Di sisi lain Ombudsman RI mengeluarkan Hasil Penilaian

13 H. A. S. Moenir, Manajemen Pelayanan Umum Di Indonesia (Bumi Aksara 2008), hlm. 88-119. 
Kepatuhan Standar Pelayanan Publik Sesuai Undang-Undang Nomor 25 Tahun 2009 Tentang Pelayanan Publik Tahun 2016 mengungkapkan kepatuhan standar pelayanan publik belum maksimal. Capaian itu jelas masih jauh dari target. Berdasarkan Rencana Pembangunan Jangka Menengah (RPJMN) pada 2016, seharusnya standar kepatuhan pelayanan publik untuk kementerian mencapai 80 persen. Demikian juga untuk Pemerintah Provinsi, dan Kabupaten/Kota.

\section{Daftar Pustaka}

Aini N, 'Domestifikasi Etnisitas: Pemekaran Wilayah Dan Rutinisasi Kekerasan Antar Etnis Di Maluku Utara' (2015) 1 Jurnal Pemikiran Sosiologi $103<$ https://jurnal.ugm. ac.id/jps/article/view/23434>

'Dampak Pemekaran Wilayah Terhadap' (2012) <http://weyagunggaalexconawiarigia. blogspot.com/2012/10/Dampak-Pemekaran-Wilayah-Terhadap.Html.> accessed 25 July 2018

Firman T, 'Territorial Splits (Pemekaran Daerah) in Decentralising Indonesia, 2000-2012: Local Development Drivers or Hindrance?' [2013] Space and Polity

Germana DH, 'Tinjauan Arah Kebijakan Pembangunan Di Daerah Pada Era Otonomi Daerah' (2017) 10 KA PEMUDA 69

H. A. S. Moenir, Manajemen Pelayanan Umum Di Indonesia (Bumi Aksara 2008)

'Https://Id.Answers.Yahoo.Com/Question/Index?Qid=20140303043133aatxilp.' <https://id.answers.yahoo.com/Question/Index?Qid=20140303043133aatxilp> accessed 25 April 2017

Khairul Ikhwan Damanik dkk, Otonomi Daerah, Etnonasionalisme, Dan Masa Depan Indonesia (Yayasan Pustaka Obor Indonesia 2010)

Ronny Hanitijo Soemitro, Metode Penelitian Hukum Dan Jurimetri (Ghalia Indonesia 1994)

Soerjono Soekamto dan Sri Mamudji, Penelitian Hukum Normatif Suatu Tinjauan Singkat (Raja Grafindo Persada 2003)

Tenrini RH, 'Pemekaran Daerah : Kebutuhan Atau Euforia Demokrasi ? Mengapa Harus Mekar' [2014] Pusat Kebijakan APBN BKF Republik Indonesia

Ubaedillah dan Abdul Rozak, Pendidikan Kewarga[Negar]an (Civic Education) Pancasila, Demokrasi, HAM, Dan Masyarakat Madani (Icce UIN Syarif Hidayatullah 2014)

Zuska F, 'Politik Etnisitas Dalam Pemekaran Daerah' (2013) 33 Antropologi Indonesia <http://journal.ui.ac.id/index.php/jai/article/view/2464>

Peraturan PemerintahRepublik Indonesia Nomor 78 Tahun 2007 tentang Tata Cara Pembentukan, Penghapusan, dan Penggabungan Daerah 